Research Article

\title{
Genetic Variation of Harmal (Peganum Harmala L. \& Rhazya Stricta Decne) Based on Polymorphism in Protein Profile, Soil Analysis and Internode Anatomy
}

\author{
Magda Elsayed Abd-Elgawad ${ }^{1,2}$, Modhi Obaidan Alotaibi ${ }^{1}$ \\ ${ }^{1}$ The Biology Department, College of Sciences, Princess Nourah Bint Abdulrahman University, Riyadh, Saudi Arabia. \\ ${ }^{2}$ The Botany Department, Faculty of Science, Fayoum University, Fayoum, Egypt. \\ Corresponding author. E-mail: m_abdelgawad@outlook.com
}

Received: May 6, 2017; Accepted: Jun. 27, 2017; Published: Jun. 30, 2017.

Citation: Magda Elsayed Abd-Elgawad, Modhi Obaidan Alotaibi, Genetic Variation of Harmal (Peganum Harmala L. \& Rhazya Stricta Decne) Based on Polymorphism in Protein Profile, Soil Analysis and Internode Anatomy. Nano Biomed. Eng., 2017, 9(2): 162-168.

DOI: 10.5101/nbe.v9i2.p162-168.

\begin{abstract}
The vernacular name 'harmal' is applied to Peganum harmala L. and another noxious weed Rhazya stricta Decne. The study aimed to clarify the genetic relationships among different populations of harmal by employing ecological, anatomical characters and a pattern of leaf protein analysis. The soil and plant samples were collected from three regions of Saudi Arabia for each species. Soil texture of the harmal populations was characterized by loamy sand and sandy. Soil type had a significant effect on the internode anatomical characters of the soil textures of both hamal populations. The anatomical characters were observed in the cuticle layer on the stem. Similarly, compact epidermis, wide cortex and many water storing tissues were observed. In the present study, it was also observed that plants have numerous cortical cells to store large amount of water, so as to fight against the dry environment. This interaction between the soil type and the plant anatomical characters was found to be well adapted to the environment of different habitats. The sodium dodecylsulphate polyacrylamide gel electrophoresis (SDS-PAGE) analysis of pattern profiles showed limited variations between the two species of harmal, which indicated the genetic similarity among populations of both species at different habitats. These variations were considered as successful adaptations leading to tolerance.
\end{abstract}

Keywords: Peganum; Rhazya; Saudi Arabia; Ecology; Anatomy; SDS-PAGE

\section{Introduction}

The flora of Saudi Arabia has one of the richest biodiversity in the Arabian Peninsula and comprises very important genetic resources of crops and medicinal plants. In addition to its large number of endemic species, the flora is an admixture of elements of Asia, Africa and the Mediterranean region [1]. Hence, Saudi Arabia has been regarded as a natural reservoir collecting a variety of wild medicinal and aromatic plants [2]. Medicinal plants are therapeutic resources much used by traditional populations of the world specifically for health care [3]. The World Health Organization [4] estimated that up to $80 \%$ of the world population relied mainly on herbal medicine for primary health care [5].

Peganum harmala L. (family Zygophyllaceae) is a perennial herbaceous plant. It is native to arid and 
semiarid rangeland, widely distributed in North Africa, the Middle East, Turkey, Pakistan, India, and Iran [6]. $P$. harmala grows in neglected areas and disturbed ground as well as along the roads. It occupies niches that receive runoff water as well as recorded rainfall [7]. P. harmala is not usually grazed due to its bitter taste that repels animals. $P$. harmala contains many pharmacologically active chemical compounds [8], such as alkaloids (harmaline, harmine, harmalol and harmol). It has been used in folk medicine as antiinflammatory [9], anticancer [10], antitumor [11], antimutagenic [12], antiprotozoal, antibacterial and antifungal agents [13]. The vernacular name of $P$. harmala is 'harmal', also applied to another noxious weed, Rhazya stricta (family Apocynaceae) [14].

Rhazya stricta Decne of Apocynaceae is a perennial dwarf shrub widely distributed in the sandy plains of Saudi Arabia and comparable habitats throughout the world [15]. It is abundantly found in Western Asia from Yemen to Saudi Arabia, to the North West Province of India and various regions of Pakistan. This plant species is considered one of the most important medicinal plants that grow in the most desert areas in the Arabian Peninsula. The vernacular name of $R$. stricta is 'harmal'. There are two reasons behind the economic value of $R$. stricta. Firstly, it functions as an invasive weed into the rangelands that causes retrogression to their ecological condition. Secondly it is a valuable native medicinal plant that needs to be preserved [16].

Leaf extracts are specified in folk medicine for the treatment of various disorders including diabetes, sore throat, syphilis, helminthiasis, inflammatory conditions and rheumatism [14]. Phytochemical analysis has identified more than 100 alkaloids [14, 17]. These alkaloids have several pharmacological properties. A recent study found that $R$. stricta extracts promoted apoptosis induction in breast cancer cells, suggesting its potential as an achemo-preventive or therapeutic agent $[18,19]$. However, currently there have been no genomic resources for $R$. stricta to facilitate the development of this species for therapeutic applications using a genomic approach on natural product [20-22].

The aim of the present investigation was to study the genetic relationships among different populations of P. harmala and R. stricta species in Saudi Arabia by employing ecological, anatomical characters and a pattern of protein analysis.

\section{Experimental Collection of plant materials}

Fresh samples representing $P$. harmala and $R$ stricta were collected from three phytogeographical regions in Saudi Arabia. P. harmala was collected from Taif region (Saseed National Park), the road of Riyadh to Mecca (Ashayrah) and the road of Mecca to Taif (AlSail AlKebeer). R. stricta was collected from the road of Taif to Riyadh (protected region; Saja \& Umm Alramth wildlife Sanctuary), Mecca region (Arafat region) and the road of Mecca to Taif (Az Zemah). Three populations of each species were collected from different locations to study the anatomical structure of internodes and the texture of soil samples and salinity.

\section{Soil analysis}

Soil samples of two species were air-dried, sieved through a $2 \mathrm{~mm}$ mesh, and were then used to measure the chemical and physical properties according to standard procedures. The $\mathrm{pH}$ and electrical conductivity (EC) values of soil samples were measured using 1:5 ratio of w/v with distilled water by $\mathrm{pH}$-meter and the electrical conductivity meter respectively. The distribution of particle size was determined according to the method of Gee and Bauder [23]. Calcium carbonate content was determined using a calcimeter [24].

\section{Anatomical studies}

Fresh samples of $P$. harmala and $R$. stricta were selected at random, and $2 \mathrm{~cm}$ in length was taken from the base of internode of a main stem for anatomical study. Microtechnique procedures done by Nassar and El-Sahhar [25] were followed. Specimens were killed and fixed for at least $48 \mathrm{~h}$ in formaldehyde acetic alcohol fixative (F.A.A.; $10 \mathrm{~mL}$ formalin, $5 \mathrm{~mL}$ glacial acetic acid, $25 \mathrm{~mL}$ distilled water, $60 \mathrm{~mL}$ ethyl alcohol 95\%). After fixation, materials were washed in $50 \%$ ethyl alcohol, dehydrated through a normal butyl alcohol series. Free hand sections were prepared by using safranin-light green or crystal violet-erythrosin combinations before mounting in Canada balsam and cover slips attached. Slides were analysed under light microscope and photomic.

\section{SDS-PAGE analysis}

For the extraction of total protein, young fresh leaves of $P$. harmala and $R$. stricta were homogenized with liquid nitrogen in mortar. Proteins were extracted from leaves in $0.1 \mathrm{~mol}$ Tris/HCl and $0.5 \mathrm{~mol} \mathrm{NaCl} \mathrm{(pH} \mathrm{8.0)} \mathrm{for} 2 \mathrm{~h}$. After spinning 
at $12,000 \mathrm{rpm}$ for $20 \mathrm{~min}$. The supernatant was collected for further use in gel electrophoresis. Protein concentrations of all the samples were measured by the protein dye binding method of Bradford at $595 \mathrm{~nm}$ using BSA as a standard [26].

The sodium dodecylsulphate polyacrylamide gel electrophoresis (SDS-PAGE) was performed by the method described by Laemmli [27]. Proteins were analysed on gels of $1.5 \mathrm{~mm}$ thick and $15 \mathrm{~cm}$ long by running in a dual vertical slab unit (Hoefer Scientific Instruments, San Francisco, CA, USA). From each sample, $25 \mu \mathrm{L}$ of protein extract was loaded on a polyacrylamide gel. The separation gel (10\%) and staking gel (3.5\%) were prepared from an acrylamide monomer solution (Roth, Karlsruhe, Germany). Protein was electrophoresed at a constant current of $30 \mathrm{~mA}$ through the stacking gel, and at $90 \mathrm{~mA}$ through the separation gel at room temperature, the gels stained by silver nitrate [28]. For quantitative measurements, a charge-coupled device camera imaging system and UVI software analysis (Gel Documentation and Analysis Systems, Uvitec, Cambridge, UK) was used to capture the image and to calculate the band intensities.

The banding patterns of SDS-PAGE for protein score and data were fed to the PC computer as 1 and 0 for the presence and absence of bands, respectively. In order to access to an overall distribution of genetic diversity, the data were analysed using Minitab 18 software.

\section{Results and Discussion}

\section{Ecological character}

The soil of the studied area was alkaline in nature with loamy sand and sandy, having a considerable amount of calcium carbonate. The soils were collected from Saseed National Park and AlSail AlKebeer for $P$. harmala and Arafat for $R$. stricta populations found on loamy sand, while the soils were collected from Ashayrah for P. harmala and Saja \& Umm Alramth Wildlife Sanctuary and Az Zemah for R. stricta populations found on sandy (Table 1 ). The $\mathrm{pH}$ of soil samples ranged from 7.60 in Ashayrah to 7.78 Saseed National Park for P. harmala and 7.51 in Saja \& Umm Alramth Wildlife Sanctuary to 7.84 in Arafat for $R$. stricta populations, which indicated the slight alkalinity of soils. As an indicator of soil salinity, electrical conductivity reached from $0.17 \mathrm{dS} / \mathrm{m}$ in Saseed
National Park to $0.53 \mathrm{dS} / \mathrm{m}$ in AlSail AlKebeer for $P$. harmala and $0.19 \mathrm{dS} / \mathrm{m}$ in Az Zemah to $1.38 \mathrm{dS} / \mathrm{m}$ in Saja \& Umm Alramth Wildlife Sanctuary for $R$. stricta populations.

Regarding the estimated chemical contents (Table 1), the amount of $\mathrm{CaCO}_{3}$ ranged from $0.33 \%$ in Ashayrah to $1.11 \%$ in Saseed National Park for P. harmala and only $1.76 \%$ in Saja \& Umm Alramth Wildlife Sanctuary for $R$. stricta populations. The amount of Na reached from 0.11 meq./L in Saseed National Park to $0.71 \mathrm{meq} . / \mathrm{L}$ in AlSail AlKebeer for $P$. harmala and 0.08 meq./L in Az Zemah to 4.05 meq./L in Saja \& Umm Alramth Wildlife Sanctuary for $R$. stricta populations. However, K value ranged from 0.41 meq./ $\mathrm{L}$ in Saseed National Park to 0.99 meq./L in Ashayrah for $P$. harmala and 0.29 meq./L in Saja \& Umm Alramth Wildlife Sanctuary to 0.42 meq./L in Arafat for $R$. stricta populations. On the other hand, the amount of $\mathrm{Cl}$ reached from 0.45 meq./L in Saseed National Park to 1.44 meq./L in AlSail AlKebeer for P. harmala and 0.30 meq./L in Az Zemah to 8.25 meq./L in Saja \& Umm Alramth Wildlife Sanctuary for $R$. stricta populations. And the amount of $\mathrm{HCO}_{3}$ reached from 0.50 meq./L in AlSail AlKebeer to 1.13 meq./L in Saseed National Park for P. harmala and 0.75 meq./L in Az Zemah to 1.13 meq./L in Saja \& Umm Alramth Wildlife Sanctuary for $R$. stricta populations (Table 1).

The soil of the studied area was alkaline in nature with loamy sand and sandy, having a considerable amount of calcium carbonate, which was typical of semi-arid and arid soils. Soil texture and structure are important factors that determine the water holding capacity of the soil for plant growth [29]. Therefore, changes in these two important factors may affect the amount of water in soil, and therefore the abundance, distribution and existence of plants in the region [30]. It was also suggested that the loamy sand type soil is the indicator of the availability of water and micronutrients for plants and thereby affecting the plant growth since the sandy soil holds less water and nutrients.

The parameters of soil salinity and conductivity wew found to be closely related to each other, because both parameters referred to the amount of ions present in the soils. The result showed similar profiles for these two parameters. The reason for this similarity between salinity and EC was that the parameters were both influenced by the amount of free ions contained in the soils, mostly $\mathrm{Na}^{+}, \mathrm{Cl}^{-}$ions and $\mathrm{CaCo}_{3}$. Subsequently, there was a direct proportional relationship between 
Table 1 Soil characteristics of P. harmala L and $R$. stricta Decne samples

\begin{tabular}{|c|c|c|c|c|c|c|c|c|c|c|c|}
\hline \multirow{2}{*}{ Sample } & \multirow{2}{*}{ Sand (\%) } & \multirow{2}{*}{ Silt (\%) } & \multirow{2}{*}{ Clay(\%) } & \multirow{2}{*}{ Soil type } & \multirow{2}{*}{ Soil pH } & \multirow{2}{*}{$\mathrm{EC}(\mathrm{dS} / \mathrm{m})$} & \multirow{2}{*}{$\mathrm{CaCO}_{3}(\%)-$} & \multicolumn{2}{|c|}{$\begin{array}{l}\text { Cations } \\
(\mathrm{meq} / \mathrm{L})\end{array}$} & \multicolumn{2}{|c|}{$\begin{array}{l}\text { Anions } \\
(\mathrm{meq} / \mathrm{L})\end{array}$} \\
\hline & & & & & & & & $\mathrm{Na}^{+1}$ & $\mathrm{~K}^{+1}$ & $\mathrm{Cl}^{-1}$ & $\mathrm{HCO}_{3}^{-1}$ \\
\hline \multicolumn{12}{|l|}{ P. harmala L. } \\
\hline Saseed National Park & 82.90 & 9.05 & 8.05 & loamy sand & 7.78 & 0.17 & 1.11 & 0.11 & 0.41 & 0.45 & 1.13 \\
\hline Ashayrah & 88.93 & 6.04 & 5.03 & sand & 7.60 & 0.40 & 0.33 & 0.42 & 0.99 & 1.05 & 0.55 \\
\hline AlSail AlKebeer & 84.91 & 4.02 & 11.07 & loamy sand & 7.73 & 0.53 & 0.93 & 0.71 & 0.83 & 1.44 & 0.50 \\
\hline \multicolumn{12}{|l|}{$R$. stricta Decne } \\
\hline $\begin{array}{l}\text { Saja \& Umm Alramth } \\
\text { Wildlife Sanctuary }\end{array}$ & 94.97 & 1.01 & 4.02 & sand & 7.51 & 1.38 & 1.76 & 4.05 & 0.29 & 8.25 & 1.13 \\
\hline Arafat & 84.91 & 12.07 & 3.02 & loamy sand & 7.84 & 0.23 & 0.00 & 0.14 & 0.42 & 1.20 & 0.85 \\
\hline Az Zemah & 88.93 & 5.03 & 6.04 & sand & 7.72 & 0.19 & 0.00 & 0.08 & 0.33 & 0.30 & 0.75 \\
\hline
\end{tabular}
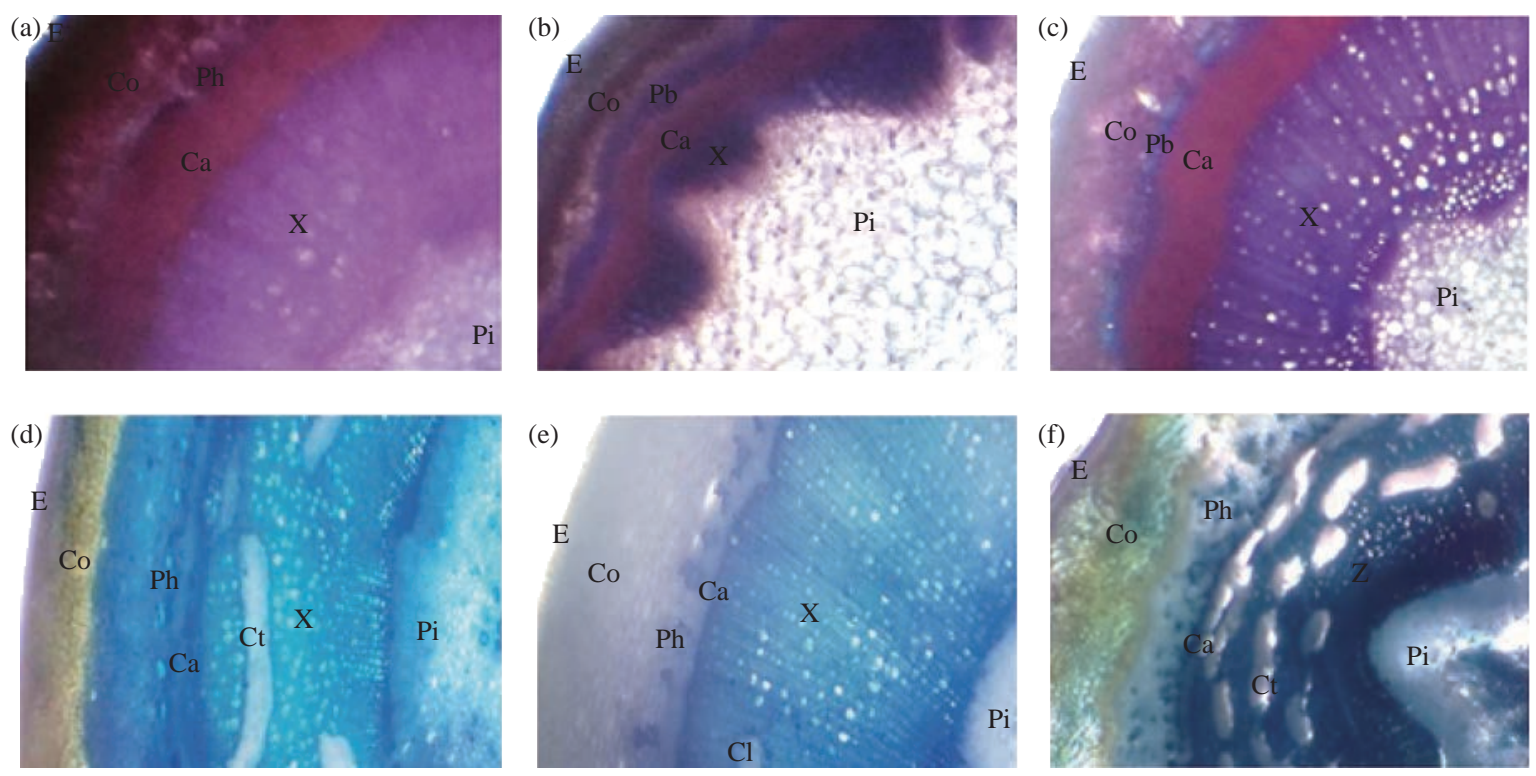

Fig. 1 Transverse sections of the basal internode of (a)-(c) P. harmala and (d)-(f) R. stricta. (a) Saseed National Park; (b) Ashayrah; (c) AlSail AlKebeer; (d) Saja \& Umm Alramth Wildlife Sanctuary; (e) Arafat; and (f) Az Zemah. (Abbr.: E: epidermis; Co: cortex; Ca: cambium; Ph: phloem; X: xylem; Ct: counjuctive tissue; Pi; pith).

each other [31, 32].

\section{Anatomical character}

The transverse sections through the basal portion of internode of the main stem of P. harmala of three populations consisted of a cuticle epidermis layer, a wide parenchymatous and sclernchymatous cortex, and radial vascular bundles and pith. The population of Saseed National Park may be similar to the population of AlSail AlKebeer in terms of sections. The cambium tissue was smaller in terms of layers in the population of Ashayrah than the other two populations. The secondary growth took place in nearly a continuous cylindrical form in Saseed National Park and AlSail AlKebeer populations. The pith tissue of Ashayrah population was considerably larger than the other two populations (Fig. 1).

Characterization of anatomical features of the stem in all three populations of $R$. stricta was performed. Sections of the three populations consisted of thick cuticle on epidermis, wide parenchymatous cortex, radial vascular bundles, endodermis and pith. Beneath the epidermis, collenchymatous cortex was found, the 

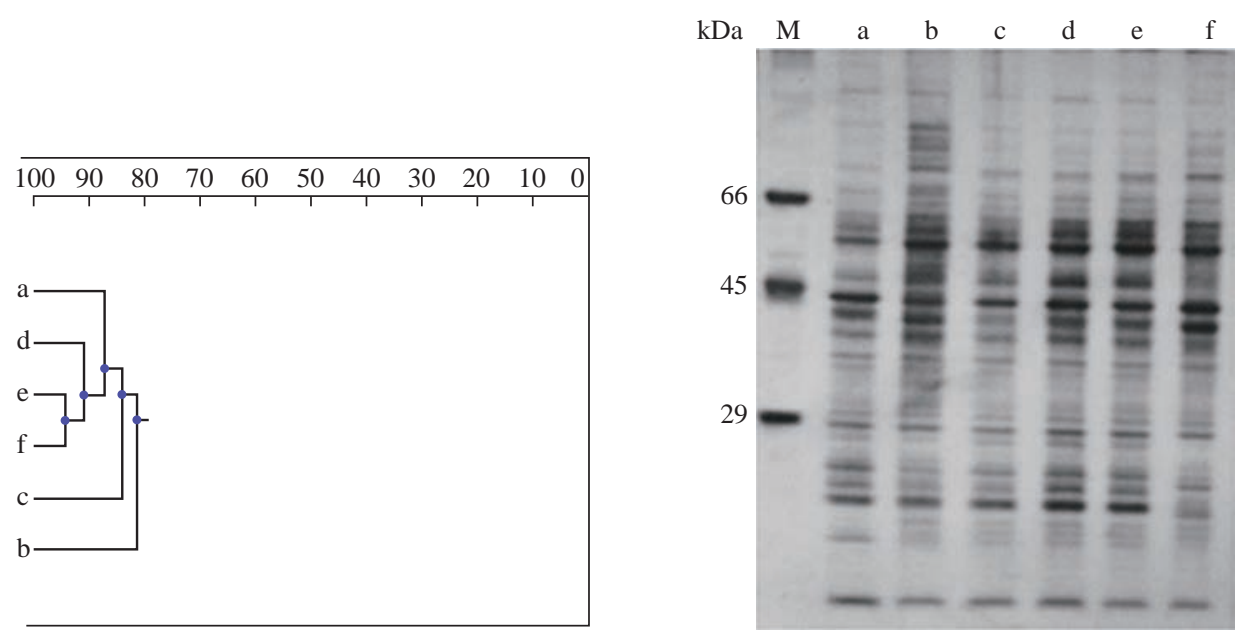

Fig. 2 The dendrogram generated by using UPGMA analysis, showing the relationships between the populations of (a)-(c) $R$. stricta and (d)-(f) P. harmala. (M) Protein marker; (a) Saja \& Umm Alramth Wildlife Sanctuary; (b) Arafat; (c) Az Zemah, 4: Saseed National Park; (e) Ashayrah; and (f) AlSail AlKebeer, using SDS-PAGE data.

layes of which were larger in the population from $\mathrm{Az}$ Zemah then that from Saja \& Umm Alramth Wldlife Sanctuary and then that from Arafat. The secondary growth took place in nearly a continuous cylindrical form in all populations. It was noticed the size of the conjunctive tissue of the Arafat population was comparatively smaller than the other two populations, although it was more connected in the Az Zemah population than in the Saja \& Umm Alramth Wildlife Sanctuary population (Fig. 1).

The anatomical features of $P$. harmala and $R$. stricta of three populations in the present study are in agreement with the description of Said and Ehsan [33]. The transverse section through the basal internode of the main stem of the two species had the same structure but with different thickness of layers (cuticle, cortex, phloem, xylem, etc). Such differences can be referred to the environmental variations. This hypothesis is supported by the present findings, whereas P. harmala of Saseed National Park population was similar to that of AlSail AlKebeer population found in the same soil structure, showing secondary growth and significant differences in the chemical contents of the soil. But they differed from the population of Ashayrah in their layers of stem tissues. Furthermore, the anatomical features of the stem of $R$. stricta from Saja \& Umm Alramth Wildlife Sanctuary were found to be similar to those from Az Zemah in the same soil structure, having large layers of conjunctive tissue and significant differences in the chemical contents of the soil. But they differed from the population of Arafat in their layers of stem tissues.
Anatomically, results from the present study are in agreement with the report of Koyuncu et al. [34], who reported that sclerenchyma cells were present in the lower cortex which provides resistance in the dry condition, and that the presence of thick cuticle on the stem surface of $P$. harmala suggested the soils were loamy sand and sandy. Vascular bundles were radially arranged in several circles from the pith towards the periphery [35]. These results are in agreement with the findings of Bibi et al., [35] on R. stricta. R. stricta had thick cuticle on epidermis, wide parenchymatous cortex and numerous radially vascular bundles. Wide cortical region and numerous vascular tissues were found. These findings supported our results that the plants had a large number of narrow vessels to overcome the environmental conditions [33].

\section{SDS-PAGE analysis}

The protein banding patterns based on SDS-PAGE were studied for $P$. harmala and $R$. stricta from three genotypes for each species. Cluster analysis of the protein markers data placed $P$. harmala and $R$. stricta into the main groups (Fig. 2), according to their previous species assignment. The genetic similarity between $P$. harmala and $R$. stricta genotypes ranged from $82 \%$ to $94 \%$ by inter-specific comparisons. The application of unweighted pair group method with arithmetic averages (UPGMA) clustering produced Arafat genotype of $R$. stricta alone and one cluster within the populations with a branched-off at the genetic similarity of $82 \%$, each consisting of several sub-clusters. The subcluster consisted of Az Zemah genotype of $R$. stricta alone and one sub-cluster within the genotypes at 
the genetic similarity of $84 \%$. As indicated by Fig. 2, the dendrogram based on the similarity matrices of protein analysis by SDS-PAGE separated at the genetic similarity of $87 \%$ into the three P. harmala and $R$. stricta genotypes and one sub-cluster, including Saseed National Park, Ashayrah, AlSail AlKebeer genotypes and Saja \& Umm Alramth Wildlife Sanctuary alone. Furthermore, $P$. harmala genotypes of Ashayrah and AlSail AlKebeer clustered together.

The protein banding patterns based on SDSPAGE were studied for P. harmala and R. stricta from three genotypes for each species. A genetic similarity between $R$. stricta and P. harmala genotypes was shown by inter-specific comparisons and intraspecific comparisons. The similarity between $R$. stricta genotypes observed in Arafat and Az Zemah was higher than that observed in Saja Umm Alramth Wildlife Sanctuary. However, the similarity between $P$. harmala genotypes observed in Ashayrah and AlSail AlKebeer was higher than that observed in Saseed National Park. The genetic similarity of harmal genotypes can be referred to the convergence of EC and indicate the similarity of soil salinity of different genotypes. On the other hand, the genotypes of high genetic similarity with low soil salinity were indicated by more protein patterns with higher intensity than the genotypes of high soil salinity. Changes in protein profiles also depended on the plant parts being studied and the nature of the plant species [7]. These changes were considered as successful adaptations leading to tolerance [7, 36].

These results agreed with other workers who used protein analysis by SDS-PAGE to study the genetic variability and the genetic relationship among the different species of Calotropis procera, wheat, Capsicum, Oryza sativa, walnut and Abrus precatorius genotypes collected from different natural habitats [3742]. SDS-PAGE analysis provided strong basis for the discrimination of genotypes on the basis of specific polypeptide fragments. Resulted profiles showed different patterns which indicated variability among populations from different habitats.

\section{Conclusions}

In summary, Soil type had a significant effect on internode anatomical characters of both species of soil textures. The analysis of soil samples collected from the selected locations indicated low values of electrical conductivity (salinity), loamy sand and sandy soil texture. The two species had distinct anatomical characters which were found to be well adapted to the environment of different habitats. The SDS-PAGE analysis illustrated distinctive qualitative alterations based on the variations in number of polypeptide bands and molecular weights. Different populations of the same species could modify genetically to determine adaptations to environmental conditions in their habitats; these tolerant populations could be considered as valuable genetic resources to be introduced to gene banks.

\section{Acknowledgements}

The authors are truthfully grateful to the Deanship of Scientific Research (Research number 1) at Princess Nourah Bint Abdulrahman University for their generous support in providing funds for availing the required facilities throughout the experimental period of this work.

\section{References}

[1] F.F. Hussein, Floristic composition and vegetationsoil relationships in Wadi Al-Argy of Taif region, Saudi Arabia. International Research Journal of Plant Science, 2012, 3(8): 147-157.

[2] H. Sher, M.N. Al-Yemeni, S.M. Yahya, et al., Ethnomedicinal and ecological evaluation of Salvadora persica L: A threatened medicinal plant in Arabian Peninsula, Journal of Medicinal Plant Research, 2010, 4(12): 1209-1215.

[3] M.A. Rather, S.A. Baba, Traditional use of medicinal plants in Kashmir: A review. Research Journal of Biology, 2015, 4(3): 26-32.

[4] World Health Organization, WHO traditional medicine strategy 2002-2005. World Health Organization, Geneva, 2002: 1-74.

[5] M. Ahvazia, F. Khalighi-Sigaroodib, M.M. Charkhchiyanc, et al., Introduction of medicinal plants species with the most traditional usage in Alamut Region. Iranian Journal of Pharmaceutical Research, 2012, 11(1): 185-194.

[6] M.A. Karam, Magda E. Abd-Elgawad, and R.M. Ali, Differential gene expression of salt-stressed Peganum harmala L. Journal of Genetic Engineering and Biotechnology, 2016, 14: 319-326.

[7] M.A. Karam, S.A. Amin, and M.E. Abd-Elgawad, Expression profiling of Zygophyllum coccineum and Peganum harmala under salt stress. The Egyptian Journal of Experimental Biology (Botany), 2011, 7(2): 261-267.

[8] T. Herraiz, D. González, C. Ancín-Azpilicueta, et al., Alkaloids in Pegannum harmala and inhibition of human monoamine oxidase (MAO). Food and Chemical Toxicology, 2010, 48: 839-845.

[9] H.R. Monsef, G. Ali, I. Mehrdad, et al., Antinociceptive effects of Peganum harmala L. alkaloid extract on mouse formalin test. Journal of Pharmacy and Pharmaceutical Sciences, 2004, 7(1): 65-69.

[10] F. Lamchouri, A. Settaf, and Y. Cherrah, Antitumour principles from Peganum harmala seeds. Therapie, 1999, 54: 753-758. 
[11] Y. Li, F. Liang, W. Jiang, et al., DH334, a beta-carboline anti-cancer drug, inhibits the CDK activity of budding yeast. Cancer Biology and Therapy, 2007, 6(8): 11931199.

[12] D.J. Moura, M.F. Richter, J.M. Boeira, et al., Antioxidant properties of beta-carboline alkaloids are related to their antimutagenic and antigenotoxic activities. Mutagen, 2007, 22(4): 293-302.

[13] M. Moloudizargari, P. Mikaili, S. Aghajanshakeri, et al., Pharmacological and therapeutic effects of Peganum harmala and its main alkaloids. Pharmacological Reviews, 2013, 7(14): 199-212.

[14] E. Adel, E.A. Mohamed, O.A. Attia, et al., In vitro multiplication of the important medicinal plant, harmal (Rhazya stricta Decne). Journal of Medicinal Plant Research, 2012, 6(19): 3586-3590.

[15] N.A. Bukhari, R.A. Al-Otaibi, and M.M. Ibhrahim, Phytochemical and taxonomic evaluation of Rhazya stricta in Saudi Arabia. Saudi Journal of Biological Sciences, 2015, xxx, xxx-xxx.

[16] E.A.M. Mohamed, E.S. Dessoky, O.A. Attia, et al., Evaluation of genetic fidelity of in vitro raised plants of the important medicinal plant Harmal (Rhazya stricta Decne) using RAPD and ISSR markers. International Journal of Agricultural Science and Research, 2014, 4(3): 115-124.

[17] S.A. Gilani, A. Kikuchi, Z. Shinwari, et al., Phytochemical, pharmacological and ethnobotanical studies of Rhazya stricta Decne. Phytotherapy Research, 2007, 21(4): 301-307.

[18] N. Baeshen, A. Elkady, O. Abuzinadah, et al., Potential anticancer activity of the medicinal herb, Rhazya stricta, against human breast cancer. African Journal of Biotechnology, 2012, 11(37): 8960-8972.

[19] M.A. El-Awady, N.S. Awad, and A.E. El-Tarras, Evaluation of the anticancer activities of pomegranate (Punica granatum) and harmal (Rhazya stricta) plants grown in Saudi Arabia. International Journal of Current Microbiology and Applied Sciences, 2015, 4(5): 11581167.

[20] I.A. Graham, K. Besser, S. Blumer, et al., The genetic map of Artemisia annua L. identifies loci affecting yield of the antimalarial drug artemisinin. Science, 2010, 327: 328-331.

[21] Y. Li, H.M. Luo, C. Sun, et al., EST analysis reveals putative genes involved in glycyrrhizin biosynthesis. BMC Genomics, 2010, 11: 268-278.

[22] S. Park, T.A. Ruhlman, J.S.M. Sabir, et al., Complete sequences of organelle genomes from the medicinal plant Rhazya stricta (Apocynaceae) and contrasting patterns of mitochondrial genome evolution across asterids. $B M C$ Genomics, 2014, 15: 405.

[23] G.W. Gee, J.W Bauder, Methods of soil analysis. Soil Science Society of America and American Society of Agronomy, 1996: 377-382.

[24] R.H. Loeppert, D.L. Suarez, Methods of soil analysis. Soil Science Society of America and American Society of Agronomy, 1996: 437- 474.

[25] M.A. Nassar, K.F. El-Sahhar, Botanical preparations and microscopy (Microtechnique). Academic Bookshop, Egypt, 1998: 219.

[26] M.M. Bradford, A rapid and sensitive method for the quantitation of microgram quantities of proteins utilizing the principle of protein-dye binding. Analytical Biochemistry, 1976, 72: 248-254.

[27] U.K. Laemmli, Cleavage of structural proteins during the assembly of the bacteriophage T4. Nature, 1970, 227: 680-685.

[28] T.G. Rabilloud, A. Carpentier, and P. Tarroux,
Improvement and simplification of low-background silver staining of proteins by using sodium dithionite. Electrophoresis, 1988, 6: 288-291.

[29] T. Wassenaar, Restoration Plan for Sendelingsdrift Mine: Adaptive Management Framework. Windhoek: African Wilderness Restoration, AWR, 2010.

[30] A. Shekunyenge, J.K.E. Mfune, T. Wassenaar, et al., Study of physical and chemical soil properties and potential of post-mining substrates as a habitat for plants during restoration at sendelingsdrif mine. A Thesis Master of Science, The University of Namibia, 2015.

[31] A.K. Fauzie, F.A. Khudsar, and Sreenivasa, Analysis of soil physico-chemical properties in various sites at Yamuna Biodiversity Park, Delhi, India. International Journal of Innovative Research in Science, Engineering and Technology, 2015a, 4: 7220-7228.

[32] A.K. Fauzie, Sreenivasa, F.A. Khudsar, et al., Impact of spatio-temporal variation in plant communities on different soil chemical properties in Yamuna Biodiversity Park, Delhi, India. International Journal of Applied Research, 2015b, 1(10): 100-106.

[33] W.M. Said, N.O.M. Ehsan, Morphological and molecular evidences among four heteroforms of Avicennia marina (Forssk) Vierh. Journal of American Science, 2010, 6(11): 843-856.

[34] O. Koyuncu, D. Ozturk, D.P. Erkara, et al., Anatomical and palynological studies on economically important Peganum harmala L., (Zygophyllaceae). Biology Diver Conservation BioDiversity, 2008, 20: 108-115.

[35] H. Bibi, M. Afzal, M. Kamal, et al., Morphological and anatomical characteristics of selected dicot xerophytes of district Karak, Khyber Pakhtunkhwa, Pakistan. Middle East Journal of Scientific Research, 2015, 23(4): 545-557.

[36] K. Shinozaki, K. Yamaguchi-Shinozaki, Gene networks involved in drought stress response and tolerance. Journal of Experimental Botany, 2007, 58(2): 221-227.

[37] M.V. Ramos, V.C. Aguiar, A.A. de Silva Xavier, et al., Latex proteins from the plant Calotropis procera are partially digested upon in vitro enzymatic action and are not immunologically detected in fecal material. Fitoterapia, 2006, 77(4): 251-256.

[38] M.F. Siddiqui, N. Naz, Protein landmarks for diversity assessment in wheat genotypes. African Journal of Biotechnology, 2009, 8(9): 1855-1859.

[39] A. Akbar, H. Ahmed, S. Ghafoor, et al., Phylogeny and genetic diversity studies in Capsicum using seed storage proteins. Current Research Journal of Biological Sciences, 2010, 2(4): 250-252.

[40] Inamullah, I.A. Khan, H. Ahmed, et al., Seed storage protein profile of rice varieties commonly grown in pakisthan. Asian Journal of Agricultural Sciences, 2010, 2(4): 120-123.

[41] M.W. Khan, I.A. Khan, H. Ahmed, et al., Estimation of genetic diversity in walnut. Pakistan Journal of Botany, 2010, 42(3): 1791-1796.

[42] M. Chittora, S.D. Purohit, Optimization of SDS-PAGE conditions and analysis of seed protein diversity in Abrus precatorius genotypes with different seed coat colour. International Journal of Life Sciences Biotechnology and Pharma Research., 2012, 1(2): 268-277.

Copyright $\left({ }^{\complement} 2017\right.$ Magda Elsayed Abd-Elgawad, Modhi Obaidan Alotaibi. This is an open-access article distributed under the terms of the Creative Commons Attribution License, which permits unrestricted use, distribution, and reproduction in any medium, provided the original author and source are credited. 